\title{
ANALYSIS OF THE ECONOMIC LOSS AND THE MAIN CAUSES OF TOTAL CONDEMNATION OF POULTRY CARCASSES UNDER BRAZILIAN FEDERAL INSPECTION BETWEEN 2013 AND 2017
} (Análise da perda econômica e das principais causas de condenações totais de
carcaças de aves sob Inspeção Federal Brasileira entre 2013 e 2017)

\author{
Weyber Ferreira de Souza ${ }^{1}$, Melissa Debesa Belizário Granjeiro ${ }^{1}$, Diego Pierotti Procópio ${ }^{1}$ \\ 'Universidade Federal de Mato Grosso
}

Corresponding author: weyberfs@gmail.com

\begin{abstract}
The present study aimed to identify the main causes of total condemnation of poultry carcasses, under Federal Inspection in the Brazilian states from 2013 to 2017 and to estimate the economic loss on these condemnations. The Brazilian poultry industry is an international highlight, being the largest exporter and the second-largest producer of chicken meat in the world. In the poultry meat production process, the adopted mechanism to ensure food safety is inspection in industry. If the carcasses showed some kind of health problem order, rendering it unfit for human consumption, they may be totally or partially condemned. The main causes identified of total condemnations were Repugnant Aspect, Contamination, Colibacillosis, and Cachexia. The estimated economic loss for the period in Brazil was US\$ 175.56 million. Actions that aim the biosafety at farm, sanitary management protocols and constant training to employees in the industry can contribute to minimizing these productive losses at slaughter.
\end{abstract}

Keywords: Repugnant appearance, contamination, poultry meat, food safety.

RESUMO: O presente estudo teve como objetivo identificar as principais causas de condenações totais de carcaças de aves, sob Inspeção Federal, nos estados brasileiros no período de 2013 a 2017 e estimar a perda econômica sobre essas condenações. A indústria avícola brasileira é destaque internacional, sendo a maior exportadora e segunda maior produtora mundial de carne de frango. No processo produtivo da carne avícola, o mecanismo adotado para a garantia da segurança dos alimentos é a fiscalização na indústria. Caso as carcaças apresentem algum tipo de problema de ordem sanitária, que as torne impróprias para o consumo humano, estas podem ser condenadas totalmente ou parcialmente. As principais causas de condenações totais identificadas foram Aspecto Repugnante, Contaminação, Colibacilose e Caquexia. A perda econômica estimada, para o período no Brasil foi de US\$ 175,56 milhões. Ações que visem a biossegurança das granjas, protocolos de manejo sanitário e treinamento constante a colaboradores na indústria podem contribuir para minimizar essas perdas produtivas ao abate.

Palavras-chave: Aspecto repugnante, contaminação, carne avícola, segurança dos alimentos. 


\section{INTRODUCTION}

Brazil ranks as the largest exporter and second-largest producer of chicken meat in the world. In the year of 2017 a total of 4,320 million tons were exported and produced about 13,056 million tons of meat. Most of the Brazilian's poultry meat production is directed to the domestic market, being the equivalent of $66 \%$ of total production. It is worth noting that the annual per capita consumption of Brazilian poultry meat increased from 37,02 kilos in 2007 to 42,07 kilos in 2017 (ABPA, 2018).

According to reports from the Department of Animal Products Inspection (DIPOA) of the Ministry of Agriculture, Livestock and Supply (MAPA), in the period from 2013 to 2017 a total of 26,69 billion birds were slaughtered in Brazil, highlighting the South region, which represented in the period, about $63 \%$ of the national total.

In order to ensure food safety and the quality of the meat marketed, sanitary inspections are carried out in the processing industries. They can be at the federal, state or municipal level, in the inspection steps ante mortem and post mortem with the objective of identifying sanitary risks in the carcass of the animal.

If any problem is identified, partial or total condemnation of the carcass may occur (Portilho, 2016).

The total of condemnations by poultry carcasses represents significant economic losses for the Brazilian poultry sector, since part of the industrialized product is no longer sold to domestic and foreign markets. Mendonça et al. (2011) emphasize the importance of investigating factors associated with the occurrence of economic losses from carcass condemnations in meat production chains.

Based on these discussions, the purpose of main goal of this article is to determine the economic loss and the main causes of total condemnation of poultry carcasses in slaughterhouses under the supervision of the Federal Inspection System (SIF) in the main Brazilian federative units producing poultry meat in the period from 2013 to 2017.

\section{MATERIALS AND METHODS}

To determine the economic losses and the analysis of the main causes of total condemnation of poultry carcasses in slaughterhouses under SIF supervision, a survey of the annual reports by the state of the Federal Inspection Service's Management Information System (SIGSIF) in the period from 2013 to 2017 and the following variables were selected: (i) total amount of slaughter per federative unit; (ii) number of total condemnations per federative unit; and, (iii) the main causes of total condemnations per federative unit.

Municipal (SIM) and state (SIE) inspection data were not used in this study, as most of them do not have public platforms to access their inspection reports. The prevalence of total condemnations per case in relation to total condemnations of poultry carcasses was determined based on the adaptation of Salines et al. (2017) and presented in Equation 1.

$$
\text { Prevalence cause }_{\text {c }}=\frac{\text { Quantitative total convictions for cause }}{\text { Quantitative total convictions }} \times 100
$$

The period analyzed was from January 2013 to December 2017. The federative units evaluated were Santa Catarina, Rio Grande do Sul, Paraná, Minas Gerais, São Paulo, Espírito Santo, Goiás, Mato Grosso, Mato Grosso do Sul, Bahia, Pernambuco, Tocantins, and Pará. These states were selected considering the availability of 
slaughtering and condemnation data by SIF in Brazil.

Thus, the determination of the economic loss will be performed from Equation 2.

$$
\text { Economic loss }_{\text {year }}=\text { NCD X AMYC X AAPPM }
$$

Where: $\quad \mathrm{NCD}=$ Number of carcasses condemned by year; $\mathrm{AMYC}=$ Average meat yield per carcass; and, AAPPM = Average annual kilo price of poultry meat.

The average meat yield per carcass is $79 \%$ according to the study by Lara et al. (2005) and the average slaughter weight of 2.5 kilos, as recommended by Ebling and Basurco (2016). Thus, the amount of meat for each poultry carcass was 1.975 kilos. The price series of the kilo of chicken meat was taken from the Agrolink portal database

(https://www.agrolink.com.br/cotacoes/hi storico/).

The price of kilo series of poultry meat was not available for all Brazilian states. Thus, for some localities, the reference price series were used. The Santa Catarina price series was used as a reference for the state of Rio Grande do Sul, while that of São Paulo served as a reference for Mato Grosso and Mato Grosso do Sul. Finally, the state of Minas Gerais was the reference for the state of Espírito Santo, Goiás, Bahia, Pernambuco, Tocantins and Pará. The criterion of selection of the proxy is the territorial proximity with the reference state.

After determining the economic loss for the analyzed period, the monetary values were updated for the year 2017 using the General Price Index (IGP-DI) determined by Getúlio Vargas Foundation (FGV).

The IGP-DI was used to compare the monetary value of a historical series to a base date value (Pereira and Ramalho, 1998).

Updates of monetary values were performed using Equation 3.

$$
\text { Real value }_{\text {year }}=\left(\frac{\text { Nominal value }_{\text {year }}}{I G P-D I_{\text {year }}}\right) \times I G P-D I_{\text {base }}
$$

Where: Real value year $=$ value of the economic loss updated for the year 2017; Nominal value year $=$ value of the estimated economic loss for each year in the period from 2013 to 2017; IGP$\mathrm{DI}_{\text {year }}=$ General Price Index for each year of the period from 2013 to 2017; and, IGP-DI base = General Price Index for the year 2017.

The dollar value was based on the historical series recorded by The Center for Advanced Studies in Applied Economics (Cepea), a part of the Department of Economics, Administration and Sociology of the "Luiz de Queiroz" School of Agriculture (Esalq) of the University of São Paulo (USP).

\section{RESULTS}

In the period of 2013 and 2017, 26.6 billion birds were slaughtered in Brazil in slaughterhouses under SIF supervision.

The states of the southern region, Paraná (with 8.72 billion), Santa Catarina (with 4.36 billion) and Rio Grande do Sul (with 3.73 billion), which jointly accounted for 16.81 billion (63\% of the national total)

(MAPA, 2018).

The first table shows the information of the total slaughter, the number of total condemnations of poultry carcasses and the economic loss in the federative units producing poultry meat from 2013 to 2017. 
Table 1. The total slaughter of poultry and total carcass condemnations, in units, and the economic loss in the Brazilian federal units from 2013 to 2017.

\begin{tabular}{ccccc}
\hline States & $\begin{array}{c}\text { total carcasses } \\
\text { slaughtered (units) }\end{array}$ & $\begin{array}{c}\text { Total carcasses } \\
\text { condemnations (units) }\end{array}$ & $\begin{array}{c}\text { Economic loss } \\
\text { (US\$) }\end{array}$ \\
\hline Santa Catarina & $\mathbf{N}$ & $\mathbf{N}$ & $\mathbf{\%}$ & \\
Rio Grande do Sul & 4.362 .877 .275 & 15.304 .654 & 0,35 & $24.160 .221,55$ \\
Paraná & 3.730 .541 .907 & 19.155 .259 & 0,51 & $31.690 .544,50$ \\
Minas Gerais & 8.725 .682 .729 & 29.163 .277 & 0,33 & $54.741 .892,72$ \\
São Paulo & 1.963 .573 .178 & 2.457 .695 & 0,13 & $5.242 .250,59$ \\
Espírito Santo & 2.650 .292 .466 & 11.018 .642 & 0,42 & $22.165 .989,26$ \\
Goiás & 147.115 .407 & 1.563 .740 & 1,06 & $3.024 .391,46$ \\
Mato Grosso & 1.833 .573 .543 & 4.922 .346 & 0,27 & $10.482 .948,06$ \\
Mato Grosso do Sul & 1.155 .568 .122 & 1.432 .372 & 0,12 & $2.402 .670,33$ \\
Distrito Federal & 820.485 .795 & 5.833 .560 & 0,71 & $11.405 .322,31$ \\
Bahia & 379.936 .256 & - & - & - \\
Paraíba & 202.107 .135 & 2.237 .362 & 1,11 & $4.970 .297,22$ \\
Pernambuco & 104.463 .475 & - & - & - \\
Tocantins & 232.187 .313 & 982.825 & 0,42 & $1.998 .226,56$ \\
Pará & 107.124 .952 & 881.999 & 0,82 & $1.777 .455,08$ \\
Rondônia & 193.018 .155 & 603.012 & 0,31 & $1.498 .174,03$ \\
Piauí & 56.079 .744 & - & - & - \\
TOTAL & 25.848 .338 & - & - & -
\end{tabular}

Source: Agrolink (2018), FGV (2018), CEPEA (2019) and MAPA (2018). Note: N - units; \% - the prevalence of total condemnations relative to the total slaughter.

The federal units of Federal District (DF), Paraíba (PB), Rondônia (RO) and Piauí (PI), although they have slaughter records, do not have total condemnation reports available on the SIF platform in the analyzed period (Table 1).

The prevalence of total condemnations of poultry carcasses in relation to total slaughter in Brazil was $0.36 \%$ for the period from 2013 to 2017 . In addition, in this case, the economic loss determined was US\$ 175.56 million (Table 1).

In relation to the Brazilian regions, the distribution percentage of the total condemnations of poultry carcasses in the South region was $66.58 \%$ of the national total, followed by the Southeast region, with a participation of $15.73 \%$ of the national total and the Center-West with a rate of $12.75 \%$ (Table 1 ). Table 2 presents information on the main causes of total condemnation of poultry carcasses in the southern region for the period from 2013 to 2017.
Table 2 shows the occurrence of total condemnation in the southern states of Rio Grande do Sul (RS), Santa Catarina (SC) and Paraná (PR), which have had the highest records of the country. The main causes of condemnation in the analyzed region were: repugnant aspect, contamination, colibacillosis, Cachexia, and ascitic syndrome.

It is worth highlighting the total condemnation of bird carcasses by repugnant aspect as being the most prevalent in all the states analyzed in the period from 2013 to 2017 . The condemnation for cachexia was more prevalent in the State of RS with a participation of $15.25 \%$, compared to PR and SC (Table 2).

Table 3 presents information on the main causes of the total condemnation of poultry carcasses, both in quantity and percentage share, in slaughterhouses located in the Southeast region from 2013 to 2017. 
Table 2. Quantity and percentage of the main causes of total condemnation of poultry carcasses in the southern states of Brazil from 2013 to 2017 period.

\begin{tabular}{|c|c|c|c|c|c|c|}
\hline \multirow[b]{2}{*}{ Main causes } & \multicolumn{2}{|c|}{$\begin{array}{l}\text { Rio Grande do Sul } \\
\text { (RS) }\end{array}$} & \multicolumn{2}{|c|}{ Paraná (PR) } & \multicolumn{2}{|c|}{ Santa Catarina (SC) } \\
\hline & $\begin{array}{c}\text { Total } \\
\text { condemnations } \\
\text { (units) }\end{array}$ & $\begin{array}{c}\text { Total } \\
(\%)\end{array}$ & $\begin{array}{c}\text { Total } \\
\text { condemnations } \\
\text { (units) }\end{array}$ & $\begin{array}{c}\text { Total } \\
(\%)\end{array}$ & $\begin{array}{c}\text { Total } \\
\text { condemnations } \\
\text { (units) }\end{array}$ & $\begin{array}{c}\text { Total } \\
(\%)\end{array}$ \\
\hline Repugnant aspect & 4.989 .701 & 26,05 & 9.805 .242 & 33,62 & 3.877 .512 & 25,34 \\
\hline Contamination & 2.222 .315 & 11,60 & 4.284 .295 & 14,69 & 2.536 .242 & 16,57 \\
\hline Colibacillosis & 1.719.842 & 8,98 & 2.236 .294 & 7,67 & 1.968 .108 & 12,86 \\
\hline Cachexia & 2.921 .113 & 15,25 & 1.933 .064 & 6,63 & 805.505 & 5,26 \\
\hline Excessive scalding & 1.381 .778 & 7,21 & 2.848 .422 & 9,77 & 954.628 & 6,24 \\
\hline Ascitic Syndrome & 1.721 .829 & 8,99 & 3.489 .485 & 11,97 & 1.203 .446 & 7,86 \\
\hline Bloody meat & 902.590 & 4,71 & 1.254 .545 & 4,30 & 130.322 & 0,85 \\
\hline Cellulitis & 476.236 & 2,49 & 1.044 .958 & 3,58 & 484.879 & 3,17 \\
\hline $\begin{array}{l}\text { Contusion / } \\
\text { Traumatic injury }\end{array}$ & 251.830 & 1,31 & 338.680 & 1,16 & 366.554 & 2,40 \\
\hline Dermatitis & 134.388 & 0,70 & 387.496 & 1,33 & 423.393 & 2,77 \\
\hline Other causes & 2.433 .637 & 12,70 & 1.540 .796 & 5,28 & 2.554 .065 & 21,95 \\
\hline TOTAL & 19.155.259 & 100,0 & 29.163.277 & 100,0 & 15.304 .654 & 100,0 \\
\hline
\end{tabular}

Source: MAPA (2018). Note:\% - The convictions percentage for each cause was determined per state in relation to the total number of convictions.

Table 3. Quantity and percentage share of the main causes of total condemnation of poultry carcasses in the states of the Southeast region of Brazil from 2013 to 2017 period.

\begin{tabular}{|c|c|c|c|c|c|c|}
\hline \multirow[b]{2}{*}{ Main causes } & \multicolumn{2}{|c|}{ São Paulo (SP) } & \multicolumn{2}{|c|}{ Minas Gerais (MG) } & \multicolumn{2}{|c|}{ Espírito Santo (ES) } \\
\hline & $\begin{array}{c}\text { Total } \\
\text { condemnations } \\
\text { (units) }\end{array}$ & $\begin{array}{c}\text { Total } \\
(\%)\end{array}$ & $\begin{array}{c}\text { Total } \\
\text { condemnations } \\
\text { (units) }\end{array}$ & $\begin{array}{c}\text { Total } \\
\text { (\%) }\end{array}$ & $\begin{array}{c}\text { Total } \\
\text { condemnations } \\
\text { (units) }\end{array}$ & $\begin{array}{c}\text { Total } \\
(\%)\end{array}$ \\
\hline $\begin{array}{l}\text { Repugnant } \\
\text { aspect }\end{array}$ & 2.677 .479 & 24,30 & 1.099 .077 & 44,72 & 86.925 & 5,56 \\
\hline Cachexia & 1.392 .959 & 12,64 & 330.274 & 13,44 & 140.962 & 9,01 \\
\hline $\begin{array}{l}\text { Hemorrhagic } \\
\text { viscera }\end{array}$ & - & - & - & - & 1.110 .930 & 71,04 \\
\hline Colibacillosis & 962.707 & 8,74 & 744 & 0,03 & 18.039 & 1,15 \\
\hline Contamination & 516.172 & 4,68 & 335.298 & 13,64 & 8 & 0,00 \\
\hline Aerosaculitis & 689.337 & 6,26 & 63.403 & 2,58 & 323 & 0,02 \\
\hline $\begin{array}{l}\text { Ascitic } \\
\text { Syndrome }\end{array}$ & 972.080 & 8,82 & 170.215 & 6,93 & 81.026 & 5,18 \\
\hline $\begin{array}{l}\text { Excessive } \\
\text { scalding }\end{array}$ & 432.319 & 3,92 & 122.704 & 4,99 & 74.432 & 4,76 \\
\hline Neoplasm & 478.302 & 4,34 & 22.860 & 0,93 & 179 & 0,01 \\
\hline $\begin{array}{l}\text { Contusion / } \\
\text { Traumatic } \\
\text { injury }\end{array}$ & 457.776 & 4,15 & 27.304 & 1,11 & 64 & 0,00 \\
\hline Other causes & 2.439 .511 & 22,14 & 285.816 & 11,63 & 50.852 & 3,25 \\
\hline TOTAL & 11.018 .642 & 100,0 & 2.457 .695 & 100,0 & 1.563 .740 & 100,0 \\
\hline
\end{tabular}

Source: MAPA (2018).Note:\% - The percentage of convictions for each cause was determined by state in relation to the total convictions.

Table 3 demonstrates that the repugnant aspect was the main cause in MG $(44.72 \%)$ and SP (24.30\%). In the ES state, the main cause was the hemorrhagic viscera for the analyzed period.
Table 4 provides information on the main causes of total condemnation of poultry carcasses, in relation to the quantity and percentage share, for the states of the Midwest region from 2013 to 2017. 
Table 4. Quantity and percentage of the main causes of total condemnation of poultry carcasses in the states of the Midwest region of Brazil from 2013 to 2017 period.

\begin{tabular}{|c|c|c|c|c|c|c|}
\hline & \multicolumn{2}{|c|}{ Mato Grosso (MT) } & \multicolumn{2}{|c|}{ Mato Grosso do Sul (MS) } & \multicolumn{2}{|c|}{ Goiás (GO) } \\
\hline Main causes & $\begin{array}{c}\text { Total } \\
\text { condemnations } \\
\text { (units) }\end{array}$ & $\begin{array}{c}\text { Total } \\
(\%)\end{array}$ & $\begin{array}{c}\text { Total } \\
\text { condemnations } \\
\text { (units) }\end{array}$ & $\begin{array}{c}\text { Total } \\
(\%)\end{array}$ & $\begin{array}{c}\text { Total } \\
\text { condemnations } \\
\text { (units) }\end{array}$ & $\begin{array}{c}\text { Total } \\
(\%)\end{array}$ \\
\hline Contamination & 351.920 & 24,57 & 1.547 .294 & 26,52 & 1.627 .271 & 33,06 \\
\hline $\begin{array}{l}\text { Repugnant } \\
\text { aspect }\end{array}$ & 159.563 & 11,14 & 1.441.392 & 24,71 & 693.269 & 14,08 \\
\hline Colibacillosis & 97.252 & 6,79 & 969.959 & 16,63 & 102.463 & 2,08 \\
\hline $\begin{array}{l}\text { Ascitic } \\
\text { Syndrome }\end{array}$ & 118.171 & 8,25 & 408.665 & 7,01 & 337.569 & 6,86 \\
\hline Cachexia & 68.621 & 4,79 & 223.394 & 3,83 & 449.839 & 9,14 \\
\hline $\begin{array}{l}\text { Excessive } \\
\text { scalding }\end{array}$ & 103.833 & 7,25 & 282.872 & 4,85 & 311.428 & 6,33 \\
\hline $\begin{array}{l}\text { Delayed } \\
\text { evisceration }\end{array}$ & 39.465 & 2,76 & 108.196 & 1,85 & 135.170 & 2,75 \\
\hline Aerosaculitis & 120.522 & 8,41 & 95.723 & 1,64 & 65.910 & 1,34 \\
\hline $\begin{array}{l}\text { Abnormal } \\
\text { coloring }\end{array}$ & - & - & 277.470 & 4,76 & - & - \\
\hline Bloody meat & 8.350 & 0,58 & 48.086 & 0,82 & 195.406 & 3,97 \\
\hline Other causes & 364.675 & 30,25 & 430.509 & 7,38 & 1.004 .021 & 21,74 \\
\hline TOTAL & 1.432.372 & 100,0 & 5.833 .560 & 100,0 & 4.922 .346 & 100,0 \\
\hline
\end{tabular}

In table 4 it is observed the main cause was contamination, with the prevalence of $33.06 \%, 26.52 \%$ and $24.57 \%$ in the federative units of MT, MS and GO, respectively. The repugnant aspect and the Colibacillosis were the 2nd and 3rd major causes registered in the analyzed region, respectively.

Table 5 presents information on the main causes of total condemnation of poultry carcasses for the states of Bahia (BA) and Pernambuco (PE) from 2013 to 2017.

In the Northeast Region, represented by the states of $B A$ and $P E$, in the analyzed period, the main cause of total condemnation of poultry carcasses was aerosaculitis in BA $(35.20 \%)$ and repugnant aspects in PE $(44.93 \%)$. Besides that, colibacillosis, contamination, and cachexia all presented relevant percentages in these federative units in the period from 2013 to 2017 (Table 5).

Table 6 presents information on the main causes of total condemnations in the states of Tocantins (TO) and Pará (PA) for the period from 2013 to 2017.

Table 6 shows that repugnant aspect, cachexia, blood meats colibacillosis and dead collected birds are the main causes of total condemnation of carcasses in $\mathrm{TO}$ and PA states, representing the Northern region for the period from 2013 to 2017. 
Table 5. Quantity and percentage of the main causes of total condemnation of poultry carcasses in the states of the Northeast region of Brazil, from 2013 to 2017 period.

\begin{tabular}{lcccc}
\hline \multicolumn{1}{c}{ Main causes } & \multicolumn{2}{c}{ Bahia (BA) } & \multicolumn{2}{c}{ Pernambuco (PE) } \\
\hline Aerosaculitis & $\begin{array}{c}\text { Total condemnations } \\
\text { (units) }\end{array}$ & $\begin{array}{c}\text { Total } \\
\mathbf{( \% )}\end{array}$ & $\begin{array}{c}\text { Total condemnations } \\
\text { (units) }\end{array}$ & $\begin{array}{c}\text { Total } \\
\text { (\%) }\end{array}$ \\
\hline Repugnant aspect & 787.525 & 35,20 & 23.070 & 2,35 \\
Colibacillosis & 353.625 & 15,81 & 441.593 & 44,93 \\
Contamination & 456.778 & 20,42 & 49.743 & 5,06 \\
Cachexia & 184.780 & 8,26 & 102.250 & 10,40 \\
Excessive scalding & 42.549 & 1,90 & 123.620 & 12,58 \\
Contusion / Traumatic injury & 107.550 & 4,81 & 31.647 & 3,22 \\
Ascitic Syndrome & 43.294 & 1,94 & 82.209 & 8,36 \\
Bloody meat & 74.339 & 3,32 & 47.661 & 4,85 \\
Delayed evisceration & 58.754 & 2,63 & 40.048 & 4,07 \\
Cellulitis & 40.721 & 1,82 & 32.367 & 3,29 \\
Other causes & 35.778 & 1,60 & 1.200 & 0,12 \\
TOTAL & 51.669 & 2,31 & 7.417 & 0,75 \\
Sour & 2.237 .362 & $\mathbf{1 0 0 , 0}$ & 982.825 & $\mathbf{1 0 0 , 0}$
\end{tabular}

Source: MAPA (2018).Note:\% - The percentage of convictions for each case was determined per state in relation to the total number of convictions.

Table 6. Quantity and percentage of the main causes of total condemnation of poultry carcasses in the North region of Brazil from 2013 to 2017.

\begin{tabular}{|c|c|c|c|c|}
\hline \multirow[b]{2}{*}{ Main causes } & \multicolumn{2}{|c|}{ Tocantins (TO) } & \multicolumn{2}{|c|}{ Pará (PA) } \\
\hline & $\begin{array}{c}\text { Total } \\
\text { condemnations } \\
\text { (units) }\end{array}$ & Total (\%) & $\begin{array}{c}\text { Total } \\
\text { condemnations } \\
\text { (units) }\end{array}$ & Total (\%) \\
\hline Repugnant aspect & 105.725 & 11,99 & 148.403 & 24,61 \\
\hline Cachexia & 103.985 & 11,79 & 141.467 & 23,46 \\
\hline Collected dead & 158.801 & 18,00 & 33.149 & 5,50 \\
\hline Bloody meat & 69.117 & 7,89 & 68.858 & 11,42 \\
\hline Colibacillosis & 109.019 & 12,36 & 18.647 & 3,09 \\
\hline Excessive scalding & 66.039 & 7,49 & 29.028 & 4,81 \\
\hline Dermatitis & 62.979 & 7,14 & 3.118 & 0,52 \\
\hline Contamination & 39.161 & 4,44 & 12.712 & 2,11 \\
\hline Aerosaculitis & 21.636 & 2,45 & 17.807 & 2,95 \\
\hline $\begin{array}{l}\text { Contusion / Traumatic } \\
\text { injury }\end{array}$ & 14.921 & 1,69 & 19.785 & 3,28 \\
\hline Other causes & 130.616 & 14,81 & 110.038 & 18,25 \\
\hline TOTAL & 881.999 & 100,0 & 603.012 & 100,0 \\
\hline
\end{tabular}

Source: MAPA (2018).Note:\% The percentage of convictions for each case was determined per state in relation to the total number of convictions.

\section{DISCUSSION}

During this studying period, Brazil recorded a total carcass condemnation rate of $0.36 \%$ in establishments under Federal Inspection. In a research made by Salines et al (2017), carcass condemnations rates were identified at different times and countries where: Canada $(2.87 \%)$, Germany $(1.57 \%)$, United States $(1.01 \%)$, France $(1.8 \%)$, Iran $(0.33 \%)$ and the United Kingdom $(1.23 \%)$. These studies did not address estimated economic loss.
This topic presents the associated factors for the occurrence of the main causes of total condemnation of poultry carcasses in slaughterhouses under SIF in Brazilian federal units.

In order to guarantee food safety and quality, the Regulation of Industrial and Sanitary Inspection of Products of Animal Origin (RIISPOA) was reissued in 2017, coming into force in 2018 therefore the period of this study used as a reference the decree 30.691 of 
1952 and other modifications, compared to the new RIISPOA, where appropriate.

Factors associated with total condemnation by repugnant aspect

The repugnant aspect was one of the main causes of total condemnation of carcasses recorded in the states of the South, Southeast and North regions (Tables 2, 3 and 6) and was the second cause of higher condemnation in the states of the Midwest and Northeast regions (Tables 4 and 5, respectively).

RIISPOA, in article 172, defined that "Repugnant meats are therefore considered and condemned for carcasses that appear to have a bad appearance, abnormal coloring, or exude medicinal and excremental, sexual or unusual odors." In article 236, it states that birds, including the hunting ones, should be condemned to putrefactive alterations, exuding ammoniacal sulfuric odor, revealing gassy crackling on palpation or modifying the color of the musculature (Brazil, 1998). The new RIISPOA addresses this theme in article 143, but without major changes compared to the previous legislation (Brazil, 2017).

In Goscinscki's study (2016), conducted in the State of Paraná, he also identified the Repugnant aspect as the main cause of total condemnation, with a prevalence of $32.32 \%$. Ferreira et al. (2012) when evaluating RS state's data, observed in the period from 2009 to 2011, the repugnant aspect represented about $19.4 \%$ of total condemnations, being the third cause of greatest occurrence.

Unlike this research, Oliveira, et al. (2016) evaluating the main causes of total and partial condemnation in poultry slaughtering in Brazil on the period from 2006 to 2011, recorded a frequency of condemnations for Repugnant Appearance of $2.2 \%$.
In addition, it is noted that the occurrence of repugnant appearance is associated with chronic and acute stress in the pre-slaughter stage, which can be considered an important factor that affects directly the quality and the appearance of the carcass (Langer, 2007). Studies had related bird stress to excessive handling with strains, especially for capture, high birds density, thermal stress during transport and waiting time for slaughter (Rui, et al., 2011; Brito, et al., 2010)

Factors associated with total condemnation by contamination

The total condemnations for contamination presented a varied occurrence among the analyzed regions. The largest records were in the Midwest (Table 4) and in the South (Table 2), which was the second largest cause of total condemnation of poultry carcasses. Oliveira et. al (2016) also identified contamination as an important cause of condemnation (total and partial) of poultry carcasses in Brazil, registering a frequency of $30.0 \%$ in the period from 2006 to 2011.

During the process of slaughtering poultry in slaughterhouses, the microbiological quality of the carcass is a fundamental factor for determining food safety that directly reflects on human health and contributes to the shelf life of processed foods (Freitas, 2015).

The total condemnations of poultry carcasses by contamination are mainly associated with the pre-slaughtering fast improves, as it compromises the emptying of the digestive system. In addition, the faults in the processing steps, during the opening of the celiomatic cavity, may occur fecal extravasation and content of the pap in the carcass (Rui et al., 2011; Freitas, 2015). 
As a strategy for reducing contamination, raising awareness about the importance of producing uniform lots, respecting pre-slaughter fasting, in case of automated evisceration, correctly calibrated equipment and providing training to employees from harvesting to processing in the industry can contribute to reducing the occurrence of contamination (Ebling and Basurco, 2016).

Among the pathogens associated with poultry farming, the Salmonella genus and its importance in food safety stand out. During the processing stages, contaminations of the environment, manipulators and cross-contamination among other contaminated birds may occur (Tessari, 2008).

Lanier et al. (2018) identified that Salmonella spp. is one of the leading causes of bacterial foodborne infections in the United States. Although rarely fatal, they cause severe gastrointestinal disorders. In the study, the liver of the bird is identified as an important vehicle for the transmission of the infection. Pathogens are believed to spread through the gastrointestinal tract.

According to RIISPOA, carcasses or part of them contaminated with feces during the slaughter process should be condemned. The carcasses, part of the carcass or organs contaminated due to contact with the floor or in any other way, will also be condemned at the discretion of the Federal Inspection (Brazil, 1997).

As a supplementary standard, MAPA allows carcass washing, depending on the extent of the contamination. The article 147 of the new RIISPOA also provides the possibility to take advantage of the carcass when the contaminated part could be completely removed. (MAPA, 1998; BRAZIL, 2017)

\section{Factors associated with total condemnation by colibacillosis}

Colibacillosis was an important cause of total condemnation of poultry carcasses in Brazil. It was highlighted in the states of BA $(20.42 \%)$, MS $(16.63 \%)$, SC $(12.86 \%)$, TO $(12.36 \%)$, and SP (8.74\%).

According to Casagrande et al. (2017) colibacillosis is one of the leading infectious causes of total condemnation of poultry carcasses and is associated with systemic or localized infection caused by pathogenic avian Escherichia coli.

Rosa et al. (2019), emphasizes that colibacillosis has a great economic impact on poultry farming because it causes great mortality and reduces the productivity of poultry. Among the factors contributing to the development of the disease are the inadequate environment, respiratory diseases, biosafety failures, and health protocols, immunosuppressive factors and animal metabolism.

The control of this pathology can be accomplished through the management of environmental conditions, including humidity control, ventilation, and water chlorination. Management can be performed with antibiotics and preventive vaccination.

In the post-mortem inspection, the findings attributed to colibacillosis were defined by the macroscopic aspects of the lesions, which may manifest as fibrinous pericarditis, fibrous perihepatitis with an enlarged liver, hepatic congestion, and inflammation of the air sacs (Caldeira, 2008). For a definitive diagnosis, the use of microbiological techniques for isolation and identification of the agent would be necessary.

According to the technical regulation of the technological and hygienic inspection of poultry meat SDA/MAPA, inflammatory processes such as arthritis, cellulitis, dermatitis, salpingitis and colibacillosis should be judged as follows: "Any organ or part of 
the carcass that presents an inflammatory process should be condemned and, if there is systemic evidence of the problem, the carcass and viscera in their entirety should be condemned" (Brazil, 1998).

\section{Factors associated with total condemnation by cachexia}

Cachexia was a prominent cause among several states, ranking as the second leading cause in the states PA $(23.46 \%)$, RS (15.25\%), SP (12.64\%) PE $(12.58 \%)$ and ES (9.01\%). In the State of Minas Gerais, it was the third leading cause of condemnation, with a $13.44 \%$ occurrence.

Paschoal et al. (2012) identified cases of cachexia as the third largest cause of total condemnation in the Northeastern PR, with a frequency of $15.82 \%$. Compared to the results obtained in this study, the prevalence of cases of cachexia in relation to total condemnations in PR was $6.63 \%$ in the analyzed period.

RIISPOA determines that animals with cachexia should be condemned, regardless of the cause of malnutrition (Brazil, 1997). The new RIISPOA maintains the condemnation of carcasses with general changes as cachexia.

Freitas (2015) classifies cachexia as a pathology that can be characterized by the reduction of muscle mass, identified mainly in the pectoral muscles and body fat, being related to factors such as (i) problems in the digestive tract; (ii) nutritional, nozzle and poisoning problems; and among others that contribute to the animal having a dehydrated muscle and with discoloration.

Factors associated with total condemnation by excessive scalding

Excessive scalding composes a set of causes that are classified as technopathies, as they are cases of carcass condemnations related to failure during animal slaughter procedures. Among the evaluated states, the ones with the highest prevalence records were PR (9.77\%), TO (7.49\%), MG $(7.25 \%)$ and $\mathrm{RS}(7.21 \%)$.

Among the factors that contribute to the occurrence of total condemnations due to excessive scalding is the paralysis of the processing line, high water temperature and deregulated equipment, which causes the carcass to have a dry or cooked muscle texture and a whitish coloration in the lower chest (Brazil, 1998).

In the period from 2013 to 2017 , carcasses with this type of alteration were sent to SIF and could be partially or totally condemned (Brazil, 1988). However, only extensive injuries should be totally condemned (Brazil, 2017).

Factors associated with total condemnation by ascitic syndrome

The cases of total condemnations for ascitic syndrome had a higher prevalence in the states of PR $(11.97 \%)$, RS $(8.99 \%)$, SP $(8.82 \%)$ and MG $(8.25 \%)$ (Tables 2 and 3 ) in the period from 2013 to 2017.

Ascitic syndrome has multifactorial origins, such as genetic, nutritional, management and environmental factors. They can be more frequent in cold times, due to the increase of pulmonary hypertension. In a study by Rosário et al. (2004), indicated that food restriction programs may contribute to the reduction of their occurrence. For Freitas (2015), ascitic syndrome is a pathology that could be associated with liver problems and tumors, where fluid accumulation occurs in the body cavity, mainly in the ventral region in birds.

In the legislation, the carcass presenting yellowish ascitic syndrome, with fibrin clumps, hemorrhage and/or adhesion of several organs should be 
condemned (Brazil, 1998). The new RIISPOA, allows partial use, providing that the lesions are restricted to parts of the carcass. In cases of extensive lesions, they should be fully condemned. (Brazil, 2017).

Factors associated with condemnation by hemorrhagic viscera

The total condemnation of carcasses by hemorrhagic viscera was recorded only in the ES state, with a prevalence of $71.04 \%$ in relation to the total number of condemnations for the period from 2013 to 2017.

According to RIISPOA, carcasses that compromise the organoleptic aspects of the viscera should be condemned, Vieira-Pinto et al. (2003), associates this change with cases of coccidiosis.

According to Yang et al. (2019), coccidiosis in chickens is caused by protozoa of the genus Eimeria spp (subclass Coccidia) and are responsible for losses of approximately US $\$ 3$ billion annually in losses to the poultry industry due to high mortality and low growth. In addition to the low efficiency and disadvantages of anti-coccidial drugs and vaccines.

\section{CONCLUSION}

The federal inspection service is essential to ensure sanitary hygienic food quality standards offered to society. The economic loss of condemnations of poultry carcasses was estimated at the US \$ 175.56 million for the period from 2013 to 2017 in Brazil, in slaughterhouses under the supervision of SIF. Among the main causes, the Repugnant Aspect, Contamination, Colibacillosis, and Cachexia stand out. These losses can be minimized by taking care of sanitary and productive management in rural properties and in the processing stages in the industry. These actions can minimize the producers' losses and contribute to the quality of the final product.

\section{REFERENCES}

AGROLINK. Séries históricas. Disponível em: https://www.agrolink.com.br/cotacoes/hi storico/ Acesso em: 28/03/2019.

ASSOCIAÇÃO BRASILEIRA DE PROTERINA ANIMAL - ABPA. Relatório anual 2018. 68 f. Brasil. 2018. Disponível em: http://abpabr.com.br/setores/avicultura/publicacoes /relatorios-anuais (acesso em 08/11/2018)

BRASIL. Ministério da Agricultura, Pecuária e Abastecimento. Secretaria de Defesa Agropecuária. Departamento de Inspeção de Produtos de Origem Animal. Decreto $n^{\circ} 30.691$, de 29 de março de 1952, alterado pelo decreto $n^{\circ}$ 1255 , de 25 de junho de 1962, decreto $\mathrm{n}^{\circ}$ 1236, de 02 de setembro de 1994, decreto $n^{\circ} 1812$, de 08 de fevereiro de 1996 e decreto $n^{\circ} 2244$, de 04 de junho de 1997. Aprova o Regulamento de Inspeção Industrial e Sanitária de Produtos de Origem Animal. Diário Oficial da Republica Federativa do Brasil, Brasília, 2018. Disponível em: https://www2.camara.leg.br/legin/fed/dec ret/1997/decreto-2244-4-junho-1997437252-publicacaooriginal-1-pe.html Acesso em: 08/11/2018

BRASIL. Ministério da Agricultura, Pecuária e Abastecimento. Secretaria de Defesa Agropecuária. Departamento de Inspeção de Produtos de Origem Animal. Decreto $n^{\circ}$ 9.013, de 29 de março de 2017. Aprova o Regulamento de Inspeção Industrial e Sanitária de Produtos de Origem Animal. Disponível em: https://www.saude.rj.gov.br/comum/code MostrarArquivo.php?C=NzU2NQ\%2C\% 2C (acessada em 26/02/2019) 
BRASIL. Portaria no 210, de 10 de novembro de 1998. Aprova o Regulamento Técnico da Inspeção Tecnológica e Higiênico Sanitária da Carne de Aves. Diário Oficial da União, Brasília, DF, 26 nov. 1998, Seção 1, p. 226. Disponivel em: http://extranet.agricultura.gov.br/sislegisconsulta/consultarLegislacao.do?operac ao=visualizar\&id=1129. Acesso em $08 / 11 / 2018$

BRITO, A. B; CARRER, S. C; VIANA, A. Distúrbios metabólicos em frangos de corte - ênfase em ascite e morte súbita. In: Anais IV Congresso Latino Americano de Nutrição Animal - IV CLANA. 2010. Disponível em: < https://data.gessulli.com.br/file/2010/12/ 01/E142916-F00001-P419.pdf> Acesso em 11/07/2019

CALDEIRA, L. G. M. Principais causas de condenação de carcaça de frango de corte na inspeção. In: DIA DOS FRANGO, 1., 2008, Lavras: Núcleo de Estudos em Ciência e Tecnologia Avícola, Universidade Federal de Lavras, 2008. Disponível em: https://docs.google.com/viewer?a=v\&pid =sites\&srcid=ZGVmYXVsdGRvbWFpbn xhdmVzZGVwb3N0dXJhfGd4OjNkNWY 0ODhmMTFhNzMwODk (Acesso em: 25/02/2019.)

CASAGRANDE R.A; MACHADO G; GUERRA P.R; et al. Pathological and bacteriological characterization on broilers totally condemned due to colibacillosis under the control of the Federal Inspection Service. Pesquisa Veterinária Brasileira. 2017, Vol.37(9) p.949-957. Disponível em: < http://dx.doi.org/10.1590/s0100-

736x2017000900009> Acesso em: 15/02/2019)

CEPEA - Centro de Estudos Avançados em Economia Aplicada - Esalq/USP. Séries históricas. Disponível em: < https://www.cepea.esalq.usp.br/br/serie- de-preco/dolar.aspx> Acesso em 05/08/2019

EBLING, P.D; BASURCO, V. Análise das perdas econômicas oriundas da condenação de carcaças nos principais estados brasileiros produtores de frangos de corte. Revista Ciências Agroveterinárias e Alimentos, v.1, p.111, 2016.Disponível em: <http://revista.faifaculdades.edu.br/index .php/cava/article/view/193>. Acesso em: 06/02/2019.

FGV - Fundação Getúlio Vargas. Indicadores de preços. Disponível em:http://portalibre.fgv.br/main.jsp?lumC hannelld=402880811D8E34B9011D92B 6B6420E96. Acesso em: 29/03/2019.

FREITAS, L. S. Causas de condenações post-mortem de frangos. 2015. 45p Monografia (Especialização) Universidade Federal do Rio Grande do Sul. Porto Alegre. 2015. Disponível em

https://lume.ufrgs.br/handle/10183/1326 81 (acessado em 15/02/2019)

GOSCINSCKI, F. Análise dos índices de condenação de carcaças de frango em abatedouros da região norte paranaense. Higiene Alimentar, 2016. v. 30, n. 260/261. Disponível em:< http://docs.bvsalud.org/biblioref/2016/11/ 2721/260-261-sitecompressed-73-77.pdf > Acesso em: 15/02/2019

LANGER; R. O. S. Efeito do transporte na incidência de PSE (palet, soft and exudative) e análogos ao DFD (dark, firm and dry) em filés de frango [dissertação]. Londrina: Universidade Estadual de Londrina; 2007. Disponível em: http://www.bibliotecadigital.uel.br/docum ent/?code $=v t l s 000123367$ Acesso em 24/03/2019.

LANIER, W. A; HALE, K. R; GEISSER, A. L; et al. Chicken Liver-Associated Outbreaks of Campylobacteriosis and Samonellosis, United States, 200-2016: 
Identifyng Opportunities for Prevention. Foodborne Pathogens and Disease. 2018, v.15 n. 11.Disponivel em: < https://doi.org/10.1089/fpd.2018.2489> Acesso em: 24/03/2019

LARA, L.J.C.; BAIÃO, N.C.; CANÇADO, S.V.; et al. Influência do peso inicial sobre o desempenho e o rendimento de carcaça e cortes de frangos de corte.

Arquivo Brasileiro de Medicina Veterinária e Zootecnia, v.57, p.799804, 2005.Disponível em: http://dx.doi.org/10.1590/S010209352005000600015 Acesso em: 06/02/2019.

$\begin{array}{lcr}\text { MAPA } & \text { MINISTÉRIO } & \text { DA } \\ \text { AGRICULTURA, } & \text { PECUÁRIA } & \text { E } \\ \text { ABASTECIMENTO. } & \text { Sistema } & \text { de }\end{array}$ Inspeção Federal. Disponível em: http://www.agricultura.gov.br/assuntos/in specao/produtos-animal/sif/servico-deinspecao-federal-sif (Acesso em: 08/11/2018).

MENDONÇA, F. S.; VAZ, R. Z.; COSTA, O. A. D.; et al. Fatores que afetam o bem-estar de bovinos durante o período pré-abate. Archivos de Zootecnia, v. 65 , n. 250, p. 279-287, 2016. Disponível em:<https://doi.org/10.21071/az.v65i250 .500> Acesso em: 23/03/2019

OLIVEIRA, A. A; ANDRADE, M. A; ARMENDARIS, $\mathrm{P}$. M; et al. Principais causas de condenação ao abate de aves em matadouros frigoríficos registrados no serviço brasileiro de inspeção federal entre 2006 e 2011. Ciência Animal Brasileira. 2016, vol.17, n.1, pp.79-89. Disponível em: http://dx.doi.org/10.1590/1089-

6891v17i123020 Acesso em: $\underline{06 / 02 / 2019}$

PASCHOAL, E. C.; OTUTUMI, L. K.; SILVEIRA, A. P. Principais causas de condenações no abate de frangos de corte de um abatedouro localizado na região noroeste do Paraná, Brasil. Arquivos de Ciências Veterinárias e Zoologia da UNIPAR, Umuarama, v.
15, n. 2, p. 93-97, jul./dez. 2012. Disponível

em: https://doi.org/10.25110/arqvet.v15i2.20 12.4209. Acesso em: 06/02/2019.

PEREIRA, A. L.; RAMALHO, W. Números Índices: conceitos e aplicações. Belo Horizonte: UFMG, 1998.

PORTILHO, E.F. Análise retrospectiva da implantação do serviço de inspeção municipal de Rio Verde - GO e de microrganismos patogênicos em produtos cárneos. 2016. 42 f. Tese (Doutorado em Medicina Veterinária) Universidade Estadual Paulista, Faculdade de Ciências Agrárias e Veterinárias. Jaboticabal, 2016. Disponível em: https://repositorio.unesp.br/bitstream/ha ndle/11449/134383/portilho_ef_dr jabo. pdf? sequence $=3$ Acesso em: 06/02/2019.

ROSA. G; SILVA, A. S; SOUZA. C. F; et al. Impact of colibacillosis on production in laying hens associated with interference of the phosphotransfer network and oxidative stress. Microbial Pathogenesis. 2019, Vol. 130, p.131136. Disponível em: https://doi.org/10.1016/j.micpath.2019.0 3.004. Acesso em 06/02/2019.

ROSARIO, M. F; SILVA, M. A. N; COELHO, A. A. D; et al. Síndrome ascítica em frangos de corte: uma revisão sobre a fisiologia, avaliação e perspectivas. Ciência Rural, v. 34, n. 6, p. 1987-1996, nov-dez, 2004. Disponível em:

http://www.scielo.br/pdf/cr/v34n6/a51v34 n6.pdf . Acesso em: 06/02/2019

RUI, B. R; ANGRIMANI, D. S. R; SILVA, M. A. A. Pontos críticos no manejo préabate de frango de corte: jejum, captura, carregamento, transporte e tempo de espera no abatedouro. Ciência Rural, Santa Maria. v.41, n.7, p. 1290-1296. 2011.Disponível

em: 
http://www.scielo.br/pdf/cr/v41n7/a4911c r4424.pdf . Acesso em: 23/03/2019

SALINES, M; ALLAIN, V; ROUL, $\mathrm{H}$; et al. Rates of and reasons for condemnation of poultry carcases: harmonised methodology at the slaughterhouse. Veterinary Record. $2017 . \quad$ Disponível em: https://veterinaryrecord.bmj.com/content /180/21/516 Acesso em: 06/02/2019.

T.Z. Ferreira, R.Sesterhenn \& L.Kindlein. Perdas econômicas das principais causas de condenações de carcaças de frangos de corte em Matadouros-Frigoríficos sob Inspeção Federal no Rio Grande do Sul, Brasil. Acta Scientiae Veterinariae. 2012. Pub. 40(1): 1021. Disponível em: http://www.ufrgs.br/actavet/40-

1/PUB\%201021.pdf Acesso em: 23/03/2019.

TESSARI, E. N. C; CARDOSO, A. L. S. $\mathrm{P}$; KANASHIRO, A. M. I; et al. Ocorrência de Salmonella spp. em carcaças de frangos industrialmente processadas, procedentes de exportações industriais do Estado de São Paulo, Brasil. Ciência Rural. 2008. Vol.38, n.9, p.2557-2560. Disponivel em: $<$

http://www.scielo.br/pdf/cr/2008nahead/ a11cr244.pdf> Acesso em: 23/03/2019.

VIEIRA-PINTO, M; MATEUS, T; SEIXAS, F; et al. The role of post mortem sanitary inspection in slaughterhouse on the detection of poultry lesions and pathological processes. Four cases of Marek compatible lesions in condemned poultry. Revista Portuguesa de Ciências Veterinárias. 2003, v. 98, n.547, p. 145-148. Disponível em: http://www.fmv.ulisboa.pt/spcv/PDF/pdf9 2003/547_145_148.pdf Acesso em: 23/03/2019

YANG, W; YANG, C; LIANG, Y; et al. Anti-coccidial properties and mechanisms of an edible herb, Bidens pilosa, and its active compounds for coccidiosis. Scientific Reports. 2019, Vol. 9 n.1 p.2896.Disponível em: < https://www.nature.com/articles/s41598019-39194-2> Acesso em 23/03/2019. $\&$ 